\title{
Autosomal dominant slowed nerve conduction velocity
}

INSERM

\section{Source}

INSERM. (1999). Orphanet: an online rare disease and orphan drug data base. Autosomal dominant slowed nerve conduction velocity. ORPHA:140481

Autosomal dominant slowed nerve conduction velocity is a hereditary demyelinating motor and sensory neuropathy characterized by slowed nerve conduction velocities, in the absence of clinically apparent neurological deficits, gait abnormalities or muscular atrophy, associated with a germline mutation in the ARGHEF10 gene. 